\title{
Drownings in the Dark: The Politics of Secret Executions in Antwerp, 1557-1565
}

\section{Isabel Casteels}

Isabel Casteels studied history at the University of Amsterdam and is currently a research fellow of the Research Foundation - Flanders. Her research interests combine the fields of cultural and anthropological history and the history of knowledge in the early modern Low Countries. She has published on religious rituals in merchant guilds in Tijdschrift voor Geschiedenis (2019) and on knowledge circulation in Enkhuizen in Tijdschrift Holland (2019). She is currently writing her doctoral dissertation on the agency of audiences attending executions during the Dutch Revolt under the supervision of Violet Soen and Johan Verberckmoes at the Early Modern History Research Group of the KU Leuven.

\begin{abstract}
Between 1557 and 1565, the Antwerp city council carried out almost all of its executions of religious dissidents by drowning them in secret. This presents a puzzle to current historiography, as historians of capital punishment have identified the public and spectacular nature of early modern executions as their defining elements. To understand these secret executions, this article traces contemporary notions of secrecy and openness using a wide range of sources, including chronicles, martyrologies, correspondences, and bailiff accounts. It argues that in this period, the concept of secrecy had more to do with closing off space than with hiding knowledge, and that both hiding and showing were important strategies in the performing of executions. The authorities did not control these; rather, by negotiating the dynamics of hiding and showing executions, the central authorities, local magistrates, and the religious groups whose members were being executed constructed their meaning and effect. As such, the case of the secret executions in Antwerp nuances the current paradigm of executions as public events orchestrated by authorities to display sovereign power.
\end{abstract}

Keywords: Antwerp, executions, secrecy, public sphere, religious dissidence

DOI 10.51750/emlc10008 - URL: http://www.emlc-journal.org

Publisher: Stichting EMLC

Copyright: The Author(s). This work is licensed under a Creative Commons Attribution-NonCommercial 4.0 International License. 


\title{
Drownings in the Dark: The Politics of Secret Executions in Antwerp, 1557-1565
}

\author{
IsABel CASTEels
}

On the night of 3 April 1560, three Anabaptists - Lenaert Pluvier, Janneken Eghels, and Maeyken de Hont - were executed in the Antwerp city prison, known as Het Steen. ${ }^{1}$ Earlier that day, they had been convicted by the urban court for being baptized as an adult - an act which, according to the anti-heresy legislation in force in the early modern Low Countries, was punishable by death. That night, they were led to a designated room, probably in the basement of Het Steen, where they were put in linen bags, closed with ropes. Then, they were drowned in wooden barrels.

The drowning of Pluvier, Eghels, and De Hont was nothing like the more familiar execution for heresy that took place in this period all over Europe. Heresy trials and executions have been described as theatrical 'plays', or as scripted rituals that followed strict rules. ${ }^{2}$ The 'ideal type' of an execution of a heretic generally followed the same pattern: the procession from prison to scaffold; the dramatic act of repentance; and, eventually, the public burning. Heavily charged with symbolism and spectacle, they were meant as an example for all subjects. The execution of the three Anabaptists in Antwerp, then, was in all aspects the opposite. Instead of a public ceremonial burning, they were drowned in secret, without any form of spectacle and without an audience. What is more, during this period in Antwerp, their fate was rather the rule than the exception. Between 1557 and 1565, the Antwerp authorities carried out almost all executions of religious dissidents mostly Anabaptists, but Calvinists as well - by drowning them in secret. Why did the authorities do so?

These secret executions present a puzzle to historians. Private executions were usually reserved for nobles as a leniency because of their social standing. ${ }^{3}$ In contrast, scholars of capital punishment have identified the public, spectacular, and theatrical characteristics of early modern executions as their defining elements. In the wake of Foucault's

1 Brussels, Algemeen Rijksarchief (hereafter ARA), Rekenkamer (hereafter Rk) 12906, Bailiff accounts, 15581560, fols. 248v-249r; Offer des Heeren, 367-372; Outerman, Historie, 275-279.

2 Gregory, Salvation at Stake; Nicholls, 'The Theatre of Martyrdom'; Flynn, 'Mimesis of the Last Judgment'; Prosperi, Crime and Forgiveness.

3 It was common in England to execute rebellious nobles within the walls of the Tower of London: Parnell, Observations on Tower Green, 320-326. See also Westerhof, Death and the Noble Body. 
paradigmatic book Surveiller et punir (1975), public executions have been regarded as instruments of state-building and displaying sovereign power. ${ }^{4}$ This was especially the case for religious crimes. As the princes of early modern Europe came to be regarded as God's representatives on earth, heresy was refashioned as a direct attack on the worldly order of things and redefined as divine and worldly lese-majesty. ${ }^{5}$ As such, the need for displaying sovereign majesty became most urgent in the case of heresy. ${ }^{6}$ The public character of early modern executions has also been emphasized by historians adopting an anthropological perspective, describing executions as redemptive collective rituals. ${ }^{7}$ As religious crimes were considered particularly dangerous for society as they corroded both the social and the moral order, purging rituals were especially important in cases of heresy. ${ }^{8}$ Burning 'to ashes' came to signify heresy repression all over Europe, not only obliterating, and thus erasing the heretic from society, but also denying the sinner resurrection. ${ }^{9}$

As the public nature of early modern executions is central to all these interpretations, the secret executions in Antwerp seemingly do not fit in. To understand how and why these particular executions were carried out in secret', this article questions the public nature of early modern executions and proposes a more nuanced analysis of the dynamics of secrecy and transparency. Focusing on what contemporaries themselves understood and labelled as secret in a cross-section of sources, such as chronicles, martyrologies, correspondences, and judicial documents, this article aims to uncover the dynamics of secrecy and publicity in execution practices. It is argued that in sixteenth-century Antwerp, the notion of secrecy related more to space, than to concealment of information. ${ }^{10}$ Rather than regulating knowledge, authorities were trying to regulate the visibility and accessibility of executions.

This new reading of secrecy, then, leads to an alternative interpretation of the 'ritual of execution'. Initially, the executions behind closed doors were a solution to the problem of heresy contamination, as religious dissidence was regarded as an infectious disease that needed to be contained. However, debates on when to resort to secret executions caused tensions between city magistrates, nobility, and the central government. This tension, in turn, was mobilized by the persecuted groups themselves through martyrological writings, and as a result, public executions began to be seen as potentially explosive occasions. As public order was now at stake, as well as public morality, city magistrates, the high nobility,

\footnotetext{
4 Foucault, Surveiller et punir; Spierenburg, The Spectacle of Suffering; Dülmen, Theatre of Horror.

5 Goosens, Les inquisitions modernes, I.

6 Monter, Heresy Executions, 48-64; Johnson and Koyama, Persecution and Toleration, 123-146. In Ireland, for example, Protestant authorities used the execution of Catholics to display their newly established sovereignty: Tait, 'Adored for Saints'.

7 For a bottom-up perspective see: Friedland, Seeing Justice Done; Laqueur, 'Crowds, Carnival, and the State'; Cohen, The Crossroads of Justice; Royer, The English Execution Narrative; Lake and Questier, 'Agency, Appropriation and Rhetoric'.

8 Davis, 'The Rites of Violence'; Murdock, Roberts, and Spicer (eds.), 'Ritual and Violence'. On the importance of notions on purity and purging, see Terpstra, Religious Refugees, 74-132.

9 Caswell, 'Flames and Ashes', 186-187. See also Barbezat, Burning Bodies; Dülmen, Theatre of Horror, 88-92. 10 For a discussion of the distinction between public and private in the Dutch Republic, see Kaplan, Divided by Faith, 173-197. See also the Centre for Privacy Studies established in 2017 at the University of Copenhagen, which focuses specifically on notions of privacy in the early modern world, and Green, 'En privé \& en public'.
} 
and the king's advisors looked to secret executions as a solution. These secret executions were not designed to display the power of the sovereign, therefore, but were instead the result of negotiations between the various levels of government, whose interests sometimes aligned but often did not. The decision to carry out these executions in secret was a function of compromise, not power.

\section{Secret Executions and Prosecution for Heresy in Antwerp}

The Antwerp city council began to favour secret drowning as a method of execution from the late 1550 s, a period when both political and religious tensions in the Low Countries were increasing steadily. Between 1557 and 1564 the Antwerp hangman carried out 160 executions, of which eighty-three for crimes in fide (table 1). Of these executions for heresy, fifty-five men and women were drowned in secret at the Antwerp Steen, sixteen were executed by sword, and only twelve by fire. It is interesting to note that only heresy resulted in execution by drowning, and that most of the victims were Anabaptists, though some Calvinists also met their end in a barrel. For the other crimes, the hangman adopted different methods. Of the seventy-two executions for thievery, forty-four were carried out by hanging, seven by decapitation, seventeen by fire, and the final four victims were broken on the wheel. These numbers clearly show that, in Antwerp during this period, you were more likely to be burnt alive for theft than for heresy, even though burning as a punishment is strongly associated with the crime of heresy. ${ }^{11}$ The remaining five executions in this period for murder, breaking of banishment, and causing public unrest - were all carried out with the sword. In total, the secret drownings for heresy formed about one third of a total of 160 executions carried out in this period. A secret drowning was the hangman's most commonly employed method of execution.

As the secret drownings were employed primarily in the punishment of heresy, it is useful to look at the organization of the repression of religious dissidence in the sixteenth-century Low Countries. Facing religious division in their ancestral and conquered lands from the 1520 s onwards, the Habsburg rulers of the Low Countries adopted a policy of Catholic homogeneity and the persecution of religious dissidents. ${ }^{12}$ Although it is often described simply as 'the Inquisition', this organization was in reality complex and multi-layered, as many levels of authority with overlapping jurisdictions dealt with the prosecution of heretics. ${ }^{13}$ In addition to the episcopal and papal inquisitors that had already been active in fighting heresy throughout the medieval period, Emperor Charles v established a novel inquisitorial function, appointed by the Habsburg ruler but confirmed by the pope, to deal with the theological examinations of dissident beliefs. Even so, it was mainly the Edict of Worms of 1521, and especially its French and Dutch version adapted for the Low Countries, that formed the legal basis of the persecution of heresy by the secular authorities. ${ }^{14}$

11 Caswell, 'Flames and Ashes'; Barbezat, Burning Bodies.

12 Duke, 'The "Inquisition"'.

13 On the organization of heresy persecution in the Low Countries, see Gielis and Soen, 'The Inquisitorial Office'; Goosens, Les inquisitions modernes, I.

14 Goosens, Les inquisitions modernes, I, 50-56. 
Table 1 Methods of execution and corresponding crimes in Antwerp, 1557-1565.

\begin{tabular}{lllllll}
\hline & Drowning & Hanging & Burning & Decapitation & Wheel & Total \\
\hline Heresy & 55 & 0 & 12 & 16 & 0 & 83 \\
Thievery & 0 & 44 & 17 & 7 & 4 & 72 \\
Other & 0 & 0 & 0 & 5 & 0 & 5 \\
Total & $\mathbf{5 5}$ & $\mathbf{4 4}$ & $\mathbf{2 9}$ & $\mathbf{2 8}$ & $\mathbf{4}$ & $\mathbf{1 6 0}$ \\
\hline
\end{tabular}

Source: ARA, Rk 12906, Bailiff accounts Antwerp, 1557-1567.

As the subsequent issuing and reissuing of anti-heresy edicts throughout the sixteenth century criminalized concrete actions that were seen as sure-fire evidence of heresy, such as the possession of heretical books, the local magistrates and provincial courts of the Low Countries were charged with their reinforcement, often without the help of an inquisitor. ${ }^{15}$

In Antwerp, punishing heresy was foremost an urban affair. ${ }^{16}$ The city of Antwerp held an exceptional position in the Low Countries when it came to the persecution of heresy. On the one hand, as the most important trading centre of the Low Countries and a hotbed of Protestantism, Antwerp functioned as a bellwether that indicated the state of the Low Countries as a whole to the central authorities in Brussels and Madrid. ${ }^{17}$ Therefore, officials as well as informants of the central authorities watched the city closely. ${ }^{18}$ On the other hand, Antwerp's importance for commerce enabled the city to negotiate its policies with the central authorities. Both Guido Marnef and Victoria Christman have emphasized the relatively 'tolerant' attitude of the city government towards religious dissidents, focusing on grace and clemency. ${ }^{19}$ Moving beyond this tolerance-intolerance debate, this article stresses the importance of this negotiation of execution practices instead of trying to assess whether the city's policy was 'tolerant', 'lenient', or 'dogmatic'.

From the 1550 s onwards, the rise of Calvinism, complete with its own structure of clandestine consistories 'under the Cross', posed a new threat to religious homogeneity. This was especially true for Antwerp, which emerged as the centre of organized and international Protestantism in the Low Countries. ${ }^{20}$ The repression of Protestants continued with renewed intensity, with the issuing of the so-called Blood Placard of 1550. This edict extended the definition of the crime of heresy to all actions that were associated with the spread of heresy, even if these were performed by Catholics, and limited the possibilities for grace. ${ }^{21}$ When Philip II succeeded Charles v in 1555 as ruler over the Low Countries, he reasserted his father's anti-heresy policy, and reissued the Blood Placard in $1556 .{ }^{22}$

15 Gielis and Soen, 'The Inquisitorial Office', 51.

16 Van Dijck, 'Tussen droom en daad'.

17 Soen, 'Habsburg Political Culture', 167.

18 Van Schelven, 'Verklikkers-rapporten over Antwerpen'.

19 Marnef, 'Multiconfessionalism in a Commercial Metropolis'; Marnef, Antwerp in the Age of the Reformation; Christman, Pragmatic Toleration. See also Te Braake, 'Opereren in een grijs gebied'.

20 Marnef, Antwerp in the Age of the Reformation, 61-87; Wells, Antwerp and the Government of Philip II, 321.

21 On grace, see Vrolijk, Recht door gratie; Schepper, 'Repressie of Clementie'.

22 The placard was reissued every year: Goosens, Les inquisitions modernes, I, 85-88. 
In dealing with the new threat of Calvinism, local magistrates drew on their earlier experiences. The first execution for heresy in Antwerp, carried out in 1525, was by drowning. ${ }^{23}$ The cleansing ritual power of water 'washing away the sins', associated with baptism or holy water, must have played a role, but the importance of the river Scheldt and the harbour as symbols of urban pride also comes to mind. ${ }^{24}$ It was during the successful $1530 \mathrm{O}$ repression of Anabaptism - the radical strand of Protestantism that rejected all forms of secular and worldly authority - that drowning as an execution method became widespread. ${ }^{25}$ It was not only adopted in the Low Countries, but also in other parts of Europe confronted with Anabaptist communities, such as Geneva and Zürich. ${ }^{26}$ Adult baptism was one of the most recognizable elements of Anabaptists, so Anabaptists did not baptize their children, which often was the grounds for their being subject to the death penalty. The analogy of drowning with baptism is likely to have played a ritualistic function in this method of punishment.

Although the early heresy placards do not mention executing in secret, it is important to note that this method was used incidentally in the face of the threats of heresy in the 1530 s. $^{27}$ In the 1550 , the regional courts of justice of the Low Countries again started to consider this as an alternative to public executions. For example, long deliberations in the Council of Flanders in 1551 on the question of whether they should execute eleven religious dissidents in secret or in public show that secret executions were a serious option. ${ }^{28}$ Indeed, in his letter to the regional courts, accompanying the 1556 reissuing of the Blood Placard, Philip also remarked on the way of punishing: regarding Anabaptists, the courts should consider if 'they thought carrying them out in secret would be more expedient'. ${ }^{29}$

\section{An Open Secret}

The dynamics of secrecy were more complex than this outline suggests, however. What did Philip II mean when he advised his councils to consider carrying out executions 'in secret' in 1556 ? Interestingly, it turns out that chroniclers from Antwerp of various confessional backgrounds were well informed about the 'secret' executions taking place in their city. Describing a prison break of three Anabaptists in 1565, the Lutheran chronicler Godevaert van Haecht informs us that:

23 Genard, 'Personen te Antwerpen', viI, 141; Van Loon, Antwerpsch chronykje, 25; De Weert, 'Chronycke van Nederland', 92; Van Haemstede, Historien, 84-85. See also Verwerft, De beul in het Markizaat van Antwerpen, $178-180$.

24 Van Dülmen, Theatre of Horror, 89-92. On the drowning of women in early modern England see also Akkerman, Invisible Agents, 110-115.

25 See on the Anabaptist movement in the Low Countries: Zijlstra, Om de ware gemeente; Mellink, De wederdopers.

26 On Anabaptism in Germany, see Hill, Baptism, Brotherhood, and Belief.

27 Muller, 'Gedenkschriften', 55; Koning, Geschiedkundige aanteekeningen, 88-90; Hoop Scheffer, Inventaris der Archiefstukken, 8. See on the specific method of drowning in a barrel: Goldschmidt, Das Ertränken im Faß.

28 Decavele, De dageraad, 439-440.

29 Philip II to the courts of justice, 30 September 1556, in Gachard, 'Analectes historiques', 234: 'ilz trouvent plus expedient de les faire exécuter en secret'. 
The regent duchess of Parma wanted them to be executed in public, and not in secret, as was done here in Antwerp for some years, when they usually drowned them in a big barrel with their heads down. But now it seems they want to do it in public again, much to the regret of all who must see it. ${ }^{30}$

As Van Haecht was a Lutheran, he might be expected to be aware of the fates of other Protestants, as he might very well fear for his life, too. However, the anonymous Catholic author of the Antwerpsch chronyckje also remarked on a public burning in 1567 that 'these were the first after it was issued that they would be drowned, secretly in het Steen, and not publicly burned'. ${ }^{31}$

Indeed, for the Antwerp city council, hiding the executions was never the aim. More than with knowledge, or communication, the contemporary notion of secrecy related to physical access to certain locations. The sources in middle Dutch consulted for this article use the words secreet or heimelijk, the sources in middle French use secret. Their meaning was different from the modern sense of 'secret', something that is hidden or meant to be kept unknown by others. Rather, these words related to space..$^{32}$ Derived from the Latin secretum which had been in use from the fifteenth century onwards, secreet meant within a closed room, secluded, isolated, separated..$^{33}$ In this sense, the word sekreet was used in Dutch to refer to the toilet. Heimelijk meant as much as 'relating to home (heim) or the household' - compare, for example, the German Heimat, which had the same etymology.

It might be better, arguably, to speak of executions behind closed doors, instead of secret ones. ${ }^{34}$ The point was to limit the accessibility to the event. Already before adopting drowning in secret as the main executing method, the Antwerp city council had tried to limit access to executions. In 1557 for example, five heretics were executed with fire in Het Steen, very early in the morning. ${ }^{35}$ Although burning someone alive obviously did not go by unnoticed, the publicity of the event was limited by executing at a less accessible location (a closed-off prison court instead of a public market square) and at a time when only very few people would be on the streets. Still, the author of the Antwerpsch Chronyckje found this execution noteworthy enough to write down in his chronicle..$^{36}$ Indeed, even though the heresy drownings took place 'secretly' in the closed off space of Het Steen, most of them were carried out at night, under the cover of darkness, to limit their accessibility even more.

30 Van Haecht, De kroniek, 24: 'Ende soude naer wille van de regente de hertoginne van Parma corts gestorven in 't openbaer en niet in 't heymelyck, gelyck men sommighe jaeren gedaen heeft tot Antwerpen, so dat men se meestal verdronck in een groote tonne met den hooft nederwaerts. Maer nou scenet dat men 't weder openbaer doen soude, tot spyt van alle die 't noode sien.'

31 Van Loon, Antwerpsch chronykje, 154: 'Dit waren d'eerste die, naer dat geordonnneert was dat men se verdrincken soude, in 't heymelyck op den Stenen en niet in 't openbaer branden en soude.'

32 This observation is based on the definitions given in the database of historical dictionaries from the Institute of Dutch language: http://gtb.ivdnt.org/ (accessed on 19 February 2020). The modern Dutch word geheim was not commonly used; it probably emerged towards the end of the sixteenth or in the early seventeenth century. 33 See Levy, 'Evaluation étymologique et sémantique du mot "secret". Note, for example, the name of the famous Vatican Secret Archive: the term refers to the fact that it was a separate and private archive belonging to the pope, not to its secrecy. The name was changed in 2019 to Vatican Apostolic Archive, for the negative nuances now associated with the term 'secret'. See also the etymology of the English term 'closet' and the secretary's cabinet.

34 Compare with Kaplan, Divided by Faith, 173-197.

35 Genard, 'Personen te Antwerpen', viII, 433-434, 437-438.

36 Van Loon, Antwerpsch chronykje, 67. 
That 'secret' did not mean hidden becomes clear most of all from the fact that after the 'secret' execution, the bodies of the executed were displayed in the most public way possible. For every execution the hangman carried out, he was also paid for transporting the body to the gallows field. Usually, the head was pinned on a spike and the body itself was positioned on a wheel. ${ }^{37}$ Significantly, the hangman was careful not to damage the body too severely, so it could still be publicly displayed. During public burnings, for instance, the bodies were not completely 'reduced to ashes', but the heads were usually displayed on spikes. Indeed, after executing the Calvinist Cornelis Halewijn in 1560, the hangman 'put out the fire, so they could present the roasted flesh on the gallows field, for the birds to feed on'. ${ }^{38}$ This practice challenges the idea that heresy punishments such as burning 'to ashes' and drowning were primarily aimed at annihilating the convicted: this annihilation only took place in a later stage, on the gallows field.

Although the Antwerp authorities relied on earlier practices, the drownings for heresy in the 1550 s and 1560 s differed from those in the 1530 . In the earlier period this punishment was mainly reserved for women, but it was now also applied to men. Punishing these men with a method usually limited to women might have been regarded as degrading and thus more severe. ${ }^{39}$ Again, the ritual inversion of baptism could have been an important reason for also drowning men. In any case, drowning in secret was not considered by the Antwerp city council as the most convenient or cheapest option - indeed, in a letter to the regent from 1565 the magistrates requested permission to execute by sword from then on, arguing that the drownings were 'not profitable because it happened in secret'.$^{\circ}$ Apparently, only seeing the drowning take place could convey its ritualistic power. Indeed, as Van Haecht's chronicle entry cited above demonstrates, the ritualistic connotations of these punishments were not lost on the chronicler. Not only did Van Haecht know about these executions taking place, he also explicitly mentioned that they were 'drowned in a large barrel with their heads down'. ${ }^{41}$ Tellingly, this remark recalls not one but two methods that were used in the first wave of Anabaptist executions, when some of the accused were hanged from the gallows upside down..$^{22}$ However, the request also suggests that for the Antwerp city council, the ritual function of drowning was less important than the practical issues of daily government.

All the evidence demonstrates, then, that executions behind closed doors were not meant to be completely hidden from the Antwerp community. On the contrary, the display of bodies after the execution suggests that the city council took great care to publicize them. Interestingly, when in 1556 Philip II advised the provincial courts to execute the

37 The women, however, were usually not displayed, but buried underneath the gallows, as is evident from the payments to the hangman. See for example ARA, Rk 12906, Bailiff accounts, 1558-1560, fol. 256v.

38 Van Haemstede, Historien, 546: 'het vuer geblust [...] om datmen het gebraden vleesch de voghelen tot spijse soude voorstellen op het Galghe velt'.

39 Van Dülmen, Theatre of Horror, 89. Although the first drowning for heresy in Antwerp involved a man, later on this method was mainly used for women.

40 Prims, 'De briefwisseling', 85-86: 'het een wreed schouwspel is en niet voordeelig daar het geheimlijk gebeurt'. The hangman had to purchase special linen bags for the drownings: ARA, Rk 12906, Bailiff accounts, $1557-1567$. 41 Van Haecht, De kroniek, 24: 'verdronck in een groote tonne met den hooft nederwaerts'.

42 Geraerts, The Prosecution of Anabaptists in Holland, 37. 
Anabaptists in secret, he emphasized that 'we consent that you can execute them in secret, provided of course their process be legitimate and according to the law, and the sentence against them publicly pronounced, according to the customs and through which good justice is carried out'. ${ }^{43}$ Rather than keeping these executions completely out of sight or unknown by their subjects, the authorities did everything they could to make them as public as possible in order to show that they conformed to the lawful procedures, while ensuring the actual act took place in camera.

Indeed, both the concealment and the communicating of policy were important tactics in early modern governance. ${ }^{44}$ Laws, placards, and proclamations were read aloud and hung in public places for everyone to see. ${ }^{45}$ Suspected criminals or witnesses were summoned to court through public proclamations. Sentences of criminals, including heretics, were publicly read and posted. Similarly, although confessions were often made under torture, they were only legally valid if they were repeated out in the open. The trials themselves were open to the public, too: the importance of transparency even becomes clear in the architecture of the tribunal itself. ${ }^{46}$ The Antwerp tribunal, like other tribunals, did not have a roof: justice was done 'underneath the open sky'. The area meant for the public was only separated from the courtroom itself by a barred fence. ${ }^{47}$

\section{Secrecy Contested}

This alternative reading of secret executions makes sense considering the reasons why authorities carried them out. For the central authorities, the only good reason for executing in secret was the risk of 'heresy contamination' of public executions - the fear for the spread of heresy through public executions. Already in the 1520s, it became clear that many Protestants actually wanted to die for their confession, so they could claim the crown of martyrdom..$^{8}$ Their sacrifices were considered testimonies of their true faith and were meant as examples for fellow believers. The central authorities thus regarded heresy as if it were a contagious disease, spread through the actions and words of heretics. The best way to deprive them of their stage was to carry out the execution not in public, but somewhere secluded. This was important not only during executions, but also when the heretic was kept in prison. ${ }^{49}$ On the other hand, the authorities wanted to set an example in public, but this only served its purpose if the heretic repented rather than use the occasion to

43 Philip II to the courts of justice, 30 September 1556, in Gachard, 'Analectes historiques', 234: 'Nous consentons que leur pourrez permettre de les faire exécuter en secret, bien entendu toutesfoiz que leur procès soit légittimement et deuement instruit, et la sentence contre iceulx publicquement pronuncée, à l'accoustumé, et selon que en bonne justice se trouvera appartenir.'

44 Griffiths, 'Secrecy and Authority'.

45 The regulations regarding proclamations are described in Laenens and Leemans, De geschiedenis van het Antwerps gerecht, 52-56. See also Deen, Amsterdam 'Moorddam', 33-35.

46 I am grateful to Nathan van Kleij for sharing his thoughts on this matter. See also Kleij, Beyond the Façade.

47 Laenens and Leemans, De geschiedenis van het Antwerps gerecht, 59-63.

48 Gregory, Salvation at Stake, 97-138.

49 Margaret of Parma to Middelburg city council, 7 November 1564, in Pekelharing, 'Bijdragen', 296. 
turn their execution into martyrdom. The solution was to enlist the help of an inquisitor, who was educated as a theologian and could assess whether a heretic would repent or not. Therefore, the king emphasized that secret executions were only allowed following consultation with an inquisitor. ${ }^{50}$

The involvement of an inquisitor posed a big problem for the city of Antwerp, as the city council feared an infringement of local privileges. ${ }^{51}$ As explained above, there never was a full-blown inquisitorial tribunal at work in the Low Countries, but Philip II did appoint a number of individual inquisitor-generals whose duty it was to assist the secular courts in implementing the anti-heresy legislation. ${ }^{52}$ By April 1557, the city council had already requested that the regent grant permission to decide autonomously whether executions should take place in public or in secret. ${ }^{53}$ Although executing in secret was also in the city's interest, the magistrates wanted to do so without the interference of the inquisitor. After that, the Antwerp city council discussed the secret strategy also with the Council of Brabant on multiple occasions. In a letter to the council dated 22 November 1558, the Antwerp city council reported on the secret execution of two Anabaptists, carried out four days earlier. ${ }^{54}$ On 28 November, the pensionary Jan Gilles replied that in the future, the city councillors should ask the court for permission if they wanted to execute in secret, and insisted that they had to send documents to Brussels regarding each case, undoubtedly for the inquisitor-general to interpret. ${ }^{55}$ However, it seems as though the magistrates only took partial note of this advice. Although they requested permission from the Chancellor of Brabant, who presided over the Council, to execute another two Anabaptists in secret in 1559, the numbers show that executing in secret became the rule instead of the exception, and no other requests for permission can be found.

Before long, however, the activities of the inquisitor-generals became part of the myth formation of the 'Spanish Inquisition'. ${ }^{56}$ Although Philip was never planning to introduce such a system, elites and inhabitants in the Low Countries exploited the fear that the Spanish king would introduce a centralized and state-controlled organization of heresy repression, modelled on the Inquisition in Spain. Before 1559, stories about the Spanish tribunal had already circulated in Antwerp, which housed the main publishing centre of the Low Countries, having been brought to the city by foreign merchants. Also, German propaganda circulating in the Low Countries warned of the 'tyrannical inquisition' that would be established here. ${ }^{57}$ The 1558 publication of the Histoire de l'estat du Pais Bas, et de la religion d'Espagne by the Spanish humanist and reformer Fransico de Enzinas heralded a

50 Philip II to the courts of justice, 30 September 1556, in Gachard, 'Analectes historiques', 231-234.

51 Marnef, Antwerp in the Age of the Reformation, 61-87; Wells, Antwerp and the government of Philip II, 230-275.

52 Soen and Gielis, 'The Inquisitorial Office', 62.

53 Wells, Antwerp and the government of Philip II, 332-333.

54 Antwerp, Stadsarchief (hereafter SAA), PK 313, Antwerp city council to Court of Brabant, 22 November 1558. 55 SAA, PK 2396, Pensionary Jan Gilles to Antwerp city council, 28 November 1558.

56 Thomas, 'De mythe van de Spaanse inquisitie'; Duke, 'A Legend in the Making', 132. On the role of political propaganda in the Dutch Revolt in general: Arnade, Beggars, Iconoclasts and Civic Patriots; Pollmann and Spicer (eds.), Public Opinion; Deen, Amsterdam 'Moorddam'; Duke, Dissident Identities.

57 Duke, 'A Legend in the Making', 129. 
new phase in the myth formation..$^{58}$ During his stay in the Low Countries, Enzinas had witnessed heresy executions in Leuven in 1543, the horrors of which he polemically described in his work. This fear increased following Philip II's 1559 proposal to reorganize the dioceses in the Low Countries, and again following the end of the Council of Trent in $1563 .{ }^{59}$ In the view of the central government, an update of the twelfth-century structure was long overdue, and it was expected that a reorganization would be an important stimulus for religious life. Yet from 1561 onwards rumours started connecting this reorganization with the introduction of the Spanish Inquisition, claiming that the new organization was just a cover to enforce the 'Inquisition'.

Both the high nobility of the Low Countries and the city of Antwerp were among the fiercest opponents of this plan. Because the Antwerp city council was afraid that the inquisitors might infringe their privileges and have a negative effect on their flourishing trade, it strongly opposed Philip's plan. ${ }^{60}$ In 1559, Antwerp had sent a delegation to Spain and successfully prevented the installation of an episcopal see in the city, for the time being, at least. ${ }^{61}$ The high nobility, for their part, feared for their position as ruling elite. ${ }^{62}$ After Philip had left for Spain in 1559, the Low Countries were, in their view, degraded to the periphery of political power, and they now had to compete with the king's trusted advisor Atoine Perrenot de Granvelle as power brokers in Brussels. ${ }^{63}$ The proposed reorganization of the dioceses would diminish their influence even more: not only would new bishops be required to have a doctorate in theology, which excluded noble families, but the bishops appointed by the king would also be attending the meetings of the States of Brabant. Moreover, Granvelle would be appointed as archbishop of Mechelen, the highest church office in the Low Countries. From the early 1560 s onwards, the dissatisfied ruling elite increasingly used the Inquisition's negative reputation in the Low Countries for their own purposes, and encouraged the formation of its mythos through propaganda campaigns. ${ }^{64}$ By orally spreading rumours, and posting handwritten bills and printed pamphlets on buildings, they stimulated this negative image. ${ }^{65}$ Indeed, in 1562 the king assured the nobles that he did not intend to introduce a Spanish Inquisition, and that they were to stop spreading false rumours. ${ }^{66}$

Interestingly, the concept of secrecy played an important role in the propaganda war against the 'Spanish Inquisition' ${ }^{67}$ Adopting the inquisitive court procedure from which its Spanish nemesis derived its name, the court could summon witnesses who sometimes

58 Enzinas, Histoire de l'estat du Pais Bas.

59 Dierickx, De oprichting der nieuwe bisdommen.

60 Wells, Antwerp and the government of Philip II, 308.

61 The delegation consisted of Godevaart Sterck, schepen Reinier van Ursel, and pensionary Jacob van Wesenbeke. See also Marnef, Antwerp in the Age of the Reformation, 21.

62 On William of Orange's attitude towards the Inquisition, see Derveaux and Soen, 'Tegen de inquisitie'.

63 Soen, Vredehandel, 41-43; Geevers, Gevallen vazallen, 41-56.

64 Thomas, 'De mythe van de Spaanse inquisitie', 340-341; Duke, 'A Legend in the Making', 29-30.

65 Duke, 'Posters, Pamphlets and Prints', 29-30; Soen and Verberckmoes, 'Broadsheets Testing Moderation', 273. Granvelle himself was well aware of the benefits of propaganda: Wouk, 'Antoine Perrenot de Granvelle'.

66 Geevers, Gevallen vazallen, 99.

67 Thomas, 'De mythe van de Spaanse inquisitie', 325. 
testified in secret. This practice led to the secretive and mysterious reputation of the inquisition and the widespread fear that no one would be safe. Moreover, rumours circulated in this period about Philip II's 'spies'. Indeed, as discussed above, the central government regarded the state of affairs in Antwerp to reflect that of the Low Countries as a whole, and Philip had several informants keeping him abreast of the latest developments. ${ }^{68}$ Granvelle, the main opponent of the high nobility of the Low Countries, was often portrayed in propaganda as whispering in Philip II's ear. ${ }^{69}$

The propaganda war of the inquisition's political adversaries played directly into the hands of Protestant propagandists. Martyrologists had always portrayed their prosecutors as cruel and unjust, but now they could exploit the climate of fear and uncertainty created by the rumours regarding the Spanish Inquisition and its secrecy. As such, the Calvinist martyrologist Adriaan Van Haemstede, in his account of the public burning of Cornelis Halewijn, emphasized that although the execution was carried out in public, sentence had been passed in secret, 'so the people did not know about it'. ' $^{\circ}$ Van Haemstede was active as a Reformed minister in Antwerp and this was where he wrote his martyrology, the first edition of which appeared in 1559, following which it was regularly reprinted with updated lists of martyrs. Van Haemstede made good use of the tensions between the central government and the Antwerp city council as well as the latter's resistance against the 'Inquisition', addressing the councillors directly in his martyrology and urging them to stop the executions. Van Haemstede also connected the council's policy of executing heretics in secret to the rumours circulating about the Inquisition, stating that 'the government of Antwerp gained a bad reputation among the foreign trade corporations, because it secretly murdered men and women in Het Steen'..$^{11}$

Moreover, Van Haemstede used the secret executions themselves as a marker for harsh repression, similar to public burnings. Although executing heretics in secret deprived them of their place in the spotlight in the theatre of martyrdom, martyrologists found new ways to publicize the deaths of their fellow believers. In doing so, they restaged them as arguments for their own righteousness or as demonstrations of the fear the authorities had for their truth. For instance, Van Haemstede account of the report of the execution of Jan de Bosschere in Antwerp in 1561, first published in the 1566 edition, uses its secret nature to go into gruesome detail to emphasize its cruelty. After 'manly and persistently' confessing his true faith during his trial, the martyrology reports, De Bosschere was secretly drowned in the night, a 'gruesome murdering', because the hangman tried to drown De Bosschere using too little water, and in the end had to stab him. ${ }^{72}$ Again, De Bosschere's case shows that these 'secret' executions were not secret at all: apparently anticipating the execution, some of his coreligionists had been walking around Het Steen that night, 'to hear how the patient would be handled'. ${ }^{73}$

68 García and Rivas, Espías de Felipe II.

69 See for this motive in propaganda prints: Horst, De Opstand in zwart-wit.

70 Van Haemstede, De Gheschiedenisse, 452: 'op dat het volc daer niet af weten soude'.

71 Van Haemstede, De Gheschiedenisse, 448: 'Maer want de Overheyt van Antwerpen onder vreemde Nacien een quaet geruchte kreech, om datse mannen ende vrouwen om des Religioens wille op den Steen heymelick vermoordden'.

72 Van Haemstede, Historien, 578: 'groote ende mannelyke stantvastigheydt bewesen'; 'grouwsame moorderije'. 73 Van Haemstede, Historien, 578: 'om te hooren hoe men met den Patient handelen soude'. 
The tale of Jan de Bosschere's execution shows that martyrologies made public what was supposed to stay hidden. Because nobody could have seen exactly what had happened during the executions, the martyrologists were given carte blanche to describe events as best suited their purpose - and this invariably meant in as gruesome a manner as possible. ${ }^{74}$ Also in describing the fate of De Bosschere's body after the execution, Van Haemstede inverted the authorities' strategy. The martyr book mentions how De Bosschere's body was displayed on the gallows field but taken away by the coreligionists to be buried, thus hiding what was supposed to stay public.

In a similar way, Het Offer des Heeren, the most influential and very popular Anabaptist collection of martyr stories, letters, and songs, reported on 'secret' executions. ${ }^{75}$ The collection was probably first published in 1562 (the first edition is now lost) and contained many stories and songs that already circulated in the preceding years. The book contains much information about martyrs from Antwerp, since the city housed one of the most important Anabaptist communities in the Low Countries. The collection might even have been produced in Antwerp and was probably widely distributed and read there. In the collection, the connection between secret executions and true faith is emphasized. In a dispute between the soon-to-be-martyred Joos Kint from Kortrijk and the bailiff of that city, the latter assured Kint that 'they will prevent him from speaking' during his execution. ${ }^{76}$ Kint replied: 'Just do that, put me bravely in a bag, and smother me during the night, so no one will see: $\mathrm{He}$, who sees through heart and soul, will see, and then the people see enough.' ${ }^{\prime 7}$ An Anabaptist song commemorating the executions of twelve martyrs in Ghent also emphasized the connection between true faith and the secret character of executions:

Because I follow the Lord's command,

with tricks evil they want

to drown me maliciously,

smother me in a tub. ${ }^{78}$

\section{From Secret to Public}

With their political and religious adversaries using the secret executions and the 'secret' Inquisition to strengthen their position as 'innocent victims', the policy of executing in secret began to look like a questionable solution to the heresy problem. By this point, however, the alternative available to the Antwerp city council was hardly any better. Protestants

74 According to Brad Gregory, the martyrologies usually provided accurate accounts of executions, precisely because there was a large audience present and people would have noticed if the martyrology was unreliable: Gregory, Salvation at Stake, 16-25.

75 Het offer des Heeren. As with most early modern bestsellers, we know it was often reprinted, but few copies have survived.

76 Het offer des Heeren, 230-231: 'Men sal v tspreken daer wel beletten.'

77 Het offer des Heeren, 231: 'So doet, steect my coenelijc in eenen sac, ende versmoort my by nachte, dat gheen menschen en sien, sietet hy die herten ende nieren doorsiet, daer sietet volcx genoech.'

78 Het offer des Heeren, 555: 'Om dat ick volge des Heeren raet/Willen sy met listen quaet/My verdrencken opstinaet/In den tobbe versmooren.' See also Vermeersch, Multimedia in de stad, 57-58. 
became more and more confrontational in their actions, encouraged by the martyrologies and the political propaganda against the Inquisition that was spread by the grandees of the Low Countries. Executions increasingly became events where authority was challenged or even denied by execution audiences. In Valenciennes, Tournai, and Leiden, for example, audiences interfered with executions, sometimes even freeing prisoners from the stake. ${ }^{79}$ In 1562, during the first synod of the Reformed Churches 'under the Cross', held in Antwerp, it had even been decided that armed resistance was allowed in order to save fellow believers. ${ }^{80}$ Not only heresy contamination, but open riot was the danger now.

To be sure, rebellion formed an integral part of urban politics in this period. The cities of the Low Countries had inherited late medieval traditions that involved revolts of burghers against urban elites ${ }^{81}$ For centuries, urban populations had been able to shift the balance of power within cities in this way, but openly defying the rule of law was something new. A riot during an execution would register as a failure on the part of the city council to keep order and peace, and seriously undermine its legitimacy as government, not only within the city but also, and more importantly, in the eyes of the central authorities. The only means the city council had at its disposal to maintain order during public executions were the civic militia, but their cooperation was not assured: notions of civic unity often prevailed over strict religious homogeneity, and they were reluctant to use force against their fellow citizens. ${ }^{82}$ Therefore, the city council sought to prevent executions from taking place in a space where such a revolt might occur. However, this was not an argument it could easily make to the central government, because then it would seem as if it was not in control of its own city; an open invitation for interference by royal troops. Instead, the Antwerp city council emphasized 'practical' reasons for executing in secret. In the letter to the Chancellor of Brabant to request autonomy regarding the decision to executing in secret, the council argued that shopkeepers and homeowners around the market square feared that their houses might be damaged from violence during executions. ${ }^{83}$

For Philip II, who had left the Low Countries in 1559 and had since resided in Spain, the importance of exemplary punishment might have been greater than the need for hiding it. Significantly, in the very first month following his return to Spain, Philip had witnessed an auto-da-fé, a spectacular and theatrical religious ritual supervised by the Spanish Inquisition, which consisted of a public penance for heresy and reading of sentences. ${ }^{84} \mathrm{After}$ the ritual, attended by hundreds of people and contested by none of them, some of the heretics were burned and others absolved. It seems plausible that Philip wanted to increase the use of ritual spectacle in his Low Countries as well, seeing the disciplining effects of the auto-da-fé.

79 Tracy, Holland under Habsburg Rule, 201-202; Duke, 'Building Heaven', 76-77; Arnade, Beggars, Iconoclasts and Civic Patriots, 72-74.

80 Gelderen, The Political Thought, 74-82.

81 Lantschner, 'Revolts and the Political Order'; Boone and Prak, 'Rulers, Patricians and Burghers'.

82 For the decisive role of the civic militia in this period in Holland, see Grayson, 'The Civic Militia'; Prak, 'Citizens, Soldiers and Civic Militias'.

83 Wells, Antwerp and the government of Philip II, 332-333.

84 Parker, Imprudent King, 86. On the Spanish ritual of auto-da-fé, see Flynn, 'Mimesis of the Last Judgment'; Bethencourt, 'The Auto da Fé'. On the importance of this event for Protestant propaganda: Civil, 'Leyenda negra'. 
The case of the execution of Christoffel Fabritius in 1564 clearly shows how explosive public heresy executions had become. The Antwerp city council had sent a request to the Chancellor of Brabant to execute Fabritius in secret, 'for the market square is still completely occupied by materials for the construction of the new town hall' ${ }^{85}$ Again, the letter referred to a more pragmatic argument to obscure the fact that the city council was actually afraid to lose control. The regent Margaret of Parma also interfered with a letter written on 31 August 1564, in which she pressed for a public execution of Fabritius and suggested his German coreligionist was released in order to avoid a diplomatic scandal. ${ }^{86}$ Although the city council had to execute Fabritius in public, they did so in as least a public manner as possible. They carried out the sentence early in the morning, around 7 am, to prevent unrest. Furthermore, Fabritius was tied to a pole inside a small wooden house, which was to be set on fire. This prevented potential rioters from freeing the heretic from the stake, but also kept the actual burning of Fabritius out of sight: the execution was public and secluded at the same time. ${ }^{87}$ Again, this practice points at the authorities' concern with regulating the accessibility and visibility of the execution, rather than its hiding.

However, things went differently than the city council had hoped. The early hour of the execution failed to prevent a large crowd from gathering on the market square. ${ }^{88}$ And what the city council feared most, indeed happened: some people in the audience began to throw rocks at the bailiff and the guards, of whom one was struck down. The rioters used the stones lying on the square for the construction works of the new city hall: the symbolic meaning of pelting the authorities with their own foundational stones must have been clear to everyone. In the correspondence with the Brussels authorities that followed, the city council desperately tried to explain the events in the most favourable way possible. They immediately sent a letter to Margaret of Parma, worried as they were that she would receive a garbled rumour of what had happened, and they urged the Antwerp deputies in Brussels to 'mitigate and acquit the case as much as possible, so that the city will not be wrongly defamed'. ${ }^{89}$ In their letters, the city councillors emphasized that they had only carried out the execution this way because Parma had ordered them to do so, against their better judgement. They also downplayed the threat posed by the audience during the execution. The stone-throwing was the work of 'misbehaving rascals and schoolboys', who were 'rash and insolent'..$^{\circ}$

85 SAA, PK 314, Margrave and city council to Chancellor of Brabant, 3 August 1564: 'zoo de groote merct noch geheellyc becommert leegt met stoffen ende materialen dienende tot het maken van den nieuwen stadthuyse'.

86 Margaret of Parma to Antwerp city council, 31 August 1564, in Genard, 'Personen te Antwerpen', IX, 184-185. 87 See also Enzinas, Histoire de l'estat du Pais Bas. This was a common method of public burning in this period. Other instances can be found in Antwerp in 1567, in Ypres in 1566, 1569, and 1570, and in Ghent in 1568: Van Hernighem, Eerste bouck, 32, 75, 77; Van Vaernewijck, Van die beroerlicke tijden, III, 250-254.

88 Genard, 'Personen te Antwerpen', viII, 205.

89 Antwerp city council to envoys in Brussels, 4 October 1564, in Genard, 'Personen te Antwerpen', VIII, 191: 'ende de sake alsoe seer versueten ende verschoonen als megelyck is, opdat nyet, tonrechte, de stadt gediffameert en worde'.

90 Informacie genomen by Meesteren Pauwelse Schuermans, 5 October 1564, in Genard, 'Personen te Antwerpen', VIII, 194: 'cleyn leckers oft jongers, slechtelyck gehabitueert'; 'groote brootdronckenheyt ende insolentie'. 
However, this public relations strategy backfired when the regent discovered that this was not entirely true. The night before the execution, a Calvinist crowd had gathered in front of Het Steen and had started singing psalms, as part of a deliberate and organized attempt to free the prisoner. The next day, a group of people, probably those who had been singing the night before, tried to prevent the execution by throwing stones. Fearing that the regent would find this enough reason to station a garrison of royal soldiers inside the city walls, the city council stressed that it had taken extra security measures by installing a civic guard. On request of the regent, the city council eventually tracked down at least one of the stone-throwers, and executed him in public as an example. This execution by sword was the first to take place in front of the newly constructed town hall. Again, the symbolic meaning of this event on this location will not have been lost.

The Fabritius case proved to the Antwerp government that public executions were far too dangerous. But the drownings in Het Steen 'caused disputes' in the community as well. Therefore, the magistrates argued, it would be better to execute the heretics in secret by sword. As beheading was considered the most honourable way to execute, the city council must have thought this would reduce the controversy. Of course, the convicts were only to be executed 'after receiving their sentence in public in the tribunal'. ${ }^{11}$ Again, it is evident that the city council actually tried to make the executions behind closed doors as public as possible, in an attempt to stave off criticism from the community and from the central authorities.

Despite all these preventive measures, the city council apparently did not dare to execute any heretics in public after Fabritius, because no more executions for heresy appear in the records. Instead, it seems as though the Antwerp magistrates turned to other, less contested executions as a kind of 'diversion' and to show that they could still ensure law and order. Strikingly, in 1565, the mayors of Antwerp suddenly decided to reintroduce the old practice, out of use for over a century, of breaking upon the wheel..$^{22}$ On 14 July, two young men accused of robbery with murder and vandalism were tied to a wheel, whereupon the hangman proceeded to break all the bones in their bodies with an iron stick. As the entire Antwerp community must have regarded these street violators as a threat to the safety of the city, these very spectacular and highly visible executions were probably intended to fulfil a uniting function in society by its scapegoating nature, meant to divert attention from the contested secret executions for religious reasons. Indeed, two Antwerp chronicles reporting on this period both describe the event, even though one of the chroniclers barely mentions any other executions. ${ }^{93}$ This suggests that the spectacular execution made a big impression on the Antwerp inhabitants.

It was clear not only to the city council, but also to the high nobility, that public executions for religious crimes were too potentially explosive. In their functions as governors of various cities and provinces in the Low Countries, it was also their responsibility to maintain order. While their resistance was initially centred against the reorganization of

91 Antwerp city council to Margaret of Parma, in Prims, 'De briefwisseling', 85-86: 'hun vonnis publiek gekregen hebbende in de vierschaar'.

92 ARA, Rk 12906, Bailiff accounts, 1565-1567, fols. 354r-354v, 372 r.

93 Van Loon, Antwerpsch chronykje, 64; De Weert, 'Chronycke van Nederland', 147. 
the dioceses and the introduction of a Spanish Inquisition, the heresy persecution itself became increasingly contested..$^{94}$ The main argument was that because of the large numbers of Protestants, rigid legislation was just no longer enforceable. Clearly, they regarded their duty to keep order as more important than religious conformity. It was decided that the Count of Egmont would be sent to Spain, primarily to urge the king to return to the Low Countries. According to Egmont's instructions, he was also to discuss 'necessary changes regarding religion', but no clear position was taken on the matter. ${ }^{95}$ When asked for his advice by the king, it seems that Egmont once again recommended the secret option, because public executions were counterproductive. Indeed, in this period the debate on the heresy problem had more to do with the way the executions were carried out than with heresy prosecution as such.

As a result of Egmont's mission, Philip II consented to convene a commission, consisting of nine bishops, theologians, and councillors, to deliberate on matters of religion. ${ }^{96} \mathrm{It}$ is important to emphasize that religious tolerance or freedom of conscience were not at stake here: the problem to be discussed was the lack of efficiency and enforceability of the heresy placards. The commission acknowledged that the current legal framework was too rigid to be carried out properly. Therefore, although the legislation should not be altered, they did plead for moderation in the enforcement of the heresy edicts and in extending the possibilities of grace for the repentant. Moreover, instead of burning at the stake, heretics should be drowned or decapitated. Once again, secret executions were presented as a solution. ${ }^{97}$ Philip II was not convinced by the pleas for moderation by either the religious commission or the nobility. In his experience, granting rights to Protestants only made matters worse. However, he did listen to some of the advice: in the letters he sent to Margaret of Parma in 1565 from the Woods of Segovia, the king's advice on the execution of three Anabaptists was that she 'should consider whether they ought not to be executed in secret in some way or other (though it is true that a public execution also serves to set an example)'.$^{8}$ The only concession Philip made, was thus executing in secret.

Yet the promulgation of the Tridentine decrees and the events of 1566 disrupted this precarious balance. In the spring, a group of gentry of different confessional convictions offered Parma the so-called Smeekschrift, a petition to suspend the 'Inquisition', a term which by then was used to refer to all heresy legislation, including the imperial placards. Not authorized to make such a decision on her own account, Parma agreed to a temporary relaxing of the edicts. ${ }^{99}$ With more room for manoeuvre because the persecutions were suspended, the underground Protestant movement came out in the open. Things got out of hand in the summer of that year, when the Beeldenstorm (Iconoclastic Fury) swept across the Low Countries, and churches, monasteries, and chapels were destroyed and

94 Soen, Vredehandel, 48-49.

95 Geevers, Gevallen vazallen, 130.

96 Soen, Geen pardon zonder paus, 125-128.

97 Soen, Vredehandel, 51.

98 Philip ir to Margaret of Parma', 17 October 1565, in Mellink and Kossmann, Texts Concerning the Revolt, 55.

99 On the moderation debate, and especially the role of pamphlets, see Verberckmoes and Soen, 'Broadsheets Testing Moderation'. On the Tridentine decrees: Soen, 'The Council of Trent', 255. 
pillaged. ${ }^{100}$ Beginning in the French-speaking part of the Netherlands, the storm reached Antwerp on 20 August.

The events of 1566 convinced the authorities in Madrid and Brussels that they had been wrong to listen to the advice of local powers, such as the city magistrates and the nobility. Once again, events proved to the king his belief that leniency in matters of faith only made things worse. Many more public executions were about to follow, especially after the establishment of the Council of Troubles, a tribunal for the punishment of the main instigators of the troubles of 1566, which handed down an unprecedented number of judgments, including banishment, execution, and confiscation. ${ }^{101}$ Still, in some cases the king continued to consider secrecy as a course of action. When the 1568 spectacular execution of the Count of Egmont and Horn caused much controversy, both in the Low Countries and beyond, Philip decided to secretly strangle the Baron of Montigny, Horn's brother, in the castle of Simancas. The king declared in his letters that the baron died from an illness and took the secret - in the modern sense of the word - to his grave. ${ }^{102}$

\section{Conclusion}

Facing the rise of Calvinism in the 1550s, authorities in the Low Countries fell back on their earlier experiences and repertoires in dealing with the repression of religious dissidents during the Anabaptist revolts of the 1530s. While executing in secret had already been used incidentally in the 1530s, by the late 1550 s it had become the standard method in Antwerp. But keeping executions 'secret' did not mean they were meant to be completely unknown, as the inhabitants were well aware of this 'open secret', and death penalties had to be announced publicly. The practice of displaying the bodies after the secret executions demonstrates that the Antwerp city council never intended to hide these executions at all: rather than relating to knowledge or communication, the notion of secrecy had a spatial meaning and should be interpreted as executions behind closed doors. Authorities were trying to limit the accessibility and visibility of these executions. The fact that the secret executions were carried out by drowning, a method that had strong symbolic, religious, and ritualistic connotations, also suggests that despite the secrecy, authorities still tried to set an example, and that hiding them completely was never the aim.

Yet from the start, tension had existed between various government actors on when to carry out executions in secret. According to the central authorities, it was up to the inquisitor to decide whether executions behind closed doors was necessary - that is, when a heretic was not likely to repent. This requirement, however, became closely entangled with resistance against the 'Inquisition', which was led by the city of Antwerp and the

100 Scheerder, De Beeldenstorm. See also the special issue by Van Bruaene, Jonckheere, and Suykerbuyk (eds.), 'Beeldenstorm'.

101 See Soen and Junot, 'User ou abuser'. The council sentenced about 10,0oo persons to death. Only around ten percent of these sentences were actually carried out, the rest were tried in absentia, leading to banishment and confiscation.

102 Van Nuffel, 'De terechtstelling'; Parker, Imprudent King, 195-213. 
high nobility of the Low Countries. Reformed martyrological propaganda drew on these tensions, inflaming violent resistance from Protestants, as is evident from Fabritius's execution. As a result of the explosive situation on the ground, the Antwerp city council's strategy of carrying out executions in secret was echoed by the advice of Philip II. In the negotiations on the enforceability of heresy legislation, secret executions were put forward as a compromise. However, this compromise did not last long, as the Beeldenstorm definitively tilted the balance towards a policy of exemplary punishment.

The Antwerp case shows that these executions cannot be seen as either redemptive collective rituals or as manifestations of sovereign power and state building, and as such nuances the public execution paradigm. Instead, they should be interpreted as the result of negotiations between various levels of authority, whose strategies were often determined by actions of the executed and the audiences of these executions themselves. The form of punishment - drowning in secret - was thus the outcome of this tense and protracted 'negotiation'. Perhaps it is time to reconfigure this debate, by delving into the more complex dynamics of negotiation and compromise in early modern executions.

\section{Bibliography}

\section{Archival Sources}

Antwerp, Stadsarchief (hereafter SAA), PK 313, Antwerp city council to Court of Brabant, 22 November 1558 (minute).

SAA, PK 314, Margrave and city council to Chancellor of Brabant, 3 August 1564 (minute).

SAA, PK 2396, Pensionary Jan Gilles to Antwerp city council, 28 November 1558.

Brussels, Algemeen Rijksarchief, Rekenkamer, 12906, Bailiff accounts, 1557-1567.

\section{Printed Sources}

Akkerman, Nadine, Invisible agents. Women and Espionage in Seventeenth-century Britain (Oxford 2018).

Arnade, Peter, Beggars, Iconoclasts and Civic Patriots. The Political Culture of the Dutch Revolt (Ithaca 2008).

Barbezat, Michael, Burning Bodies. Communities, Eschatology, and the Punishment of Heresy in the Middle Ages (Ithaca 2018).

Bellman, Beryl, 'The Paradox of Secrecy', Human Studies 4 (1981) 1-24.

Bethencourt, Francisco, 'The Auto da Fé. Ritual and Imagery', Journal of the Warburg and Courtauld Institutes 55 (1992) 155-168.

Bjola, Corneliu, and Stuart Murray, Secret Diplomacy. Concepts, Contexts and Cases (London 2016).

Blockmans, Wim, “Crisme de leze magesté”. Les idées politiques de Charles le Téméraire’, in Jean M. Duvosquel, Jacques Nazet, and André Uyttebrouck (eds.), Mélanges André Uyttebrouck (Brussels 1996) 71-81.

Boone, Marc, and Maarten Prak, 'Rulers, Patricians and Burghers. The Great and the Little Traditions of Urban Revolt in the Low Countries', in Karel Davids and Jan Lucassen (eds.), A Miracle Mirrored. The Dutch Republic in European Perspective (Cambridge 1995) 99-134.

Braake, Serge ter, 'Opereren in een grijs gebied. De rol van de ambtenaren bij het Hof van Holland bij de kettervervolging (1525-1560)', Tijdschrift voor Geschiedenis 122 (2009/3) 306-319.

Caswell, Marisha, 'Flames and Ashes. The Significance of Death by Burning in Europe, 1400-180o', International Journal of Arts \& Sciences 9 (2016/3) 185-192.

Christman, Victoria, Pragmatic Toleration. The Politics of Religious Heterodoxy in Early Reformation Antwerp, 1515-1555 (Rochester 2015). 
Civil, Pierre, 'Leyenda negra y represión antiprotestante. Hispanissche Inquisition, una estampa polémica del Auto de Fe de Valladolid de 1559', in Michel Boeglin, Ignasi Fernández Terricabras, and David Kahn (eds.), Reforma y disidencia religiosa. La recepción de las doctrinas reformadas en la península ibérica en el siglo XVI (Madrid 2018) 351-363.

Cohen, Esther, The Crossroads of Justice. Law and Culture in Late Medieval France (Leiden 1993).

Davis, Natalie Zemon, 'The Rites of Violence. Religious Riot in Sixteenth-Century France', Past \& Present 59 (1973) 51-91.

De Schepper, Hugo, 'Repressie of clementie in de Nederlanden onder Karel V en Filips II', in Paul Nève, Beatrix Jacobs, and Chris Coppens (eds.), Een rijk gerecht. Opstellen aangeboden aan prof. mr. P.L. Nève (Nijmegen 1998) 341-364.

Decavele, Johan, De dageraad van de Reformatie in Vlaanderen (1520-1565) (Leuven 1975).

Deen, Femke, Amsterdam 'Moorddam'. Publiek debat en propaganda in Amsterdam tijdens de Nederlandse Opstand, 1566-1578 (Amsterdam 2015).

Derveaux, Tom, and Violet Soen, 'Tegen 'de inquisitie'. Willem van Oranje en diens vroege propaganda tegen de geloofsvervolging in de Habsburgse Nederlanden (1559-1568)', Revue belge de Philologie et d'Histoire 98 (2020) 49-74.

Dierickx, Michel, De oprichting der nieuwe bisdommen in de Nederlanden onder Filips II, 1559-1570 (Antwerp 1950).

Duke, Alastair, 'A Legend in the Making. News of the "Spanish Inquisition" in the Low Countries in German Evangelical Pamphlets, 1546-1550', Nederlandsch Archief voor Kerkgeschiedenis 71 (1997) 125-144.

Duke, Alastair, 'Building Heaven in Hell's Despite. The Early History of the Reformation in the Towns of the Low Countries', in Alastair Duke (ed.), Reformation and Revolt in the Low Countries (London 1990) 71-100.

Duke, Alastair, Dissident Identities in the Early Modern Low Countries. Judith Pollmann and Andrew Spicer (eds.) (Aldershot 2009).

Duke, Alastair, 'Posters, Pamphlets and Prints. The Ways and Means of Disseminating Dissident Opinions on the Eve of the Dutch Revolt', Dutch Crossing 27 (2003/1) 23-44.

Duke, Alastair, "The "Inquisition" and the repression of religious dissent in the Habsburg Netherlands, 1521-1566', in Alastair Duke, Dissident Identities in the Early Modern Low Countries. Judith Pollmann and Andrew Spicer (eds.) (Aldershot 2009) 99-118.

Dülmen, Richard van, Theatre of Horror. Crime and Punishment in Early Modern Germany (Oxford 1990).

Egmond, Florike, 'The Cock, the Dog, the Serpent, and the Monkey. Reception and Transmission of a Roman Punishment, or Historiography as History', International Journal of the Classical Tradition 2 (1995/2) 159-192.

Enzinas, Francisco de, Histoire de l'estat du Pais Bas, et de la religion d'Espagne (Ste. Marie aux Mines [Strasbourg]: Pierre Estiart, 1558).

Flynn, Maureen, 'Mimesis of the Last Judgment. The Spanish Auto de fe', Sixteenth Century Journal 22 (2006/2) 281-297.

Foucault, Michel, Surveiller et punir. Naissance de la prison (Paris 1975).

Frédéricq, Paul, Corpus documentorum inquisitionis haereticae pravitatis Neerlandicae. Verzameling van stukken betreffende de pauselijke en bisschoppelijke Inquisitie in de Nederlanden (Ghent 1889).

Friedland, Paul, Seeing Justice Done. The Age of Spectacular Capital Punishment in France (Oxford 2012).

Gachard, Louis-Prosper, 'Lettre de Philippe II aux conseils de justice des Pays-Bas, touchant l'observation des placards sur la religion, la surveillance à exercer sur les jeux de rhétorique, et la manière d'exécuter les anabaptistes, 30-9-1556', in Compte-rendu des séances de la commission royale d'histoire 11 (1858) 231-234.

Gelderen, Martin van, The Political Thought of the Dutch Revolt, 1555-1590 (Cambridge 1992).

Genard, Pierre, 'Personen te Antwerpen in de XVIe eeuw voor het feit van religie vervolgd', Antwerpsch Archievenblad 7 (1870) 114-471, 8 (1871) 1-472, and 9 (1872), 1-471.

Geraerts, Jaap, The Prosecution of Anabaptists in Holland, 1530-1566. MA thesis, Utrecht University, 2010. 
Gielis, Gert, and Violet Soen, 'The Inquisitorial Office in the Sixteenth-Century Habsburg Low Countries. A Dynamic Perspective', The Journal of Ecclesiastical History 66 (2015/1) 47-66.

Goldschmidt, Heinz, Das Ertränken im Faß. Eine alte Todesstrafe in den Niederlanden, 2 vols. (Stuttgart 1925-1926).

Goosens, Aline, Les inquisitions modernes dans les Pays-Bas méridionaux 1520-1633, 2 vols. (Brussels 1997).

Grayson, J. C. 'The Civic Militia in the County of Holland, 1560-81. Politics and Public Order in the Dutch Revolt', BMGN/Low Countries Historical Review 95 (1980/1) 35-63.

Gregory, Brad, Salvation at Stake. Christian Martyrdom in Early Modern Europe (Cambridge 1999).

Griffiths, Paul, 'Secrecy and Authority in Late Sixteenth- and Seventeenth-Century London', The Historical Journal 40 (1997/4) 925-951.

Het offer des Heeren. Samuel Cramer and Frederik Pijper (eds.) (The Hague 1904).

Hill, Kat, Baptism, Brotherhood, and Belief in Reformation Germany. Anabaptism and Lutheranism, 15251585 (Oxford 2015).

Hoop Scheffer, Jacob G. de, Inventaris der Archiefstukken berustende bij de Vereenigde Doopsgezinde Gemeente te Amsterdam (Amsterdam 1883).

Horst, Daniel R., De Opstand in zwart-wit. Propagandaprenten uit de Nederlandse Opstand 1566-1584 (Zutphen 2003).

Johnson, Noel D., and Mark Koyama, Persecution and Toleration. The Long Road to Religious Freedom (Cambridge 2019).

Junot, Yves, and Violet Soen, 'User ou abuser des confiscations. Les voies tortueuses de la punition, du pardon et de la récompense par les Habsbourg d'Espagne durant la Révolte (Pays-Bas espagnols, 15661609)', in Yves Junot and Violet Soen (eds.), Confisquer, restituer, redistribuer. Punition et réconciliation matérielles dans les territoires des Habsbourg et en France (XVIe et XVIIe siècles) (Valenciennes 2020) 87-132.

Jütte, Daniel, The Age of Secrecy. Jews, Christians, and the Economy of Secrets, 1400-180o (New Haven 2015).

Kaplan, Benjamin, Divided by Faith. Religious Conflict and the Practice of Toleration in Early Modern Europe (Cambridge, MA 2007).

Kleij, Nathan van, Beyond the Façade. Town Halls, Publicity, and Urban Society in the Fifteenth-Century Low Countries. PhD diss., University of Amsterdam, 2021.

Koning, Jacobus, Geschiedkundige aanteekeningen, betrekkelijk de lijfstraffelijke regtsoefening te Amsterdam, voornamelijk in de zestiende eeuw (Amsterdam 1828).

Laenens, Charles, and Leo Leemans, De geschiedenis van het Antwerps gerecht (Antwerp 1953).

Lake, Peter, and Michael Questier, 'Agency, Appropriation and Rhetoric under the Gallows. Puritans, Romanists and the State in Early Modern England', Past \& Present 153 (1996) 64-107.

Lantschner, Patrick, 'Revolts and the Political Order of Cities in the Late Middle Ages', Past \& Present 225 (2014/1) 3-46.

Laqueur, Thomas, 'Crowds, Carnival, and the State in English Executions, 1604-1868', in Lawrence Stone et al (eds.), The First Modern Society. Essays in English History in Honour of Lawrence Stone (Cambridge 1989) 305-356.

Levy, Arnaud, 'Evaluation étymologique et sémantique du mot "secret", Nouvelle revue française de psychanalyse 14 (1976) 117-129.

Marnef, Guido, Antwerp in the Age of the Reformation. Underground Protestantism in a Commercial Metropolis, 1550-1577 (Baltimore 1996).

Marnef, Guido, 'Multiconfessionalism in a Commercial Metropolis. The Case of 16th-Century Antwerp', in Thomas Max Safley (ed.), A Companion to Multiconfessionalism in the Early Modern World (Leiden 2011) 75-97.

Mellink, Albert F., De wederdopers in de noordelijke Nederlanden, 1531-1544 (Leeuwarden 1981).

Mellink, Albert. F., and Ernst H. Kossmann, Texts Concerning the Revolt of the Netherlands (London 1974).

Minkley, Gary, and Martin Legassick, "Not Telling”. Secrecy, Lies, and History', History and Theory 39 (2000/4) 1-10.

Monter, William, Heresy Executions in Reformation Europe, 1520-1565 (Cambridge 2002). 
Muller, Samuel, 'Gedenkschriften van Jhr. Herberen van Mijnden', Bijdragen en mededeelingen van het Historisch Genootschap 11 (1888) 1-69.

Murdock, Graeme, Penny Roberts, and Andrew Spicer (eds.), 'Ritual and violence. Natalie Zemon Davis and Early Modern France', Past \& Present Supplement 7 (2012).

Netten, Djoeke van, 'Geheime praktijken?! Zeventiende-eeuwse geheimen en waar ze te vinden', Jaarboek de zeventiende eeuw 2 (2018) 9-19.

Nicholls, David, 'The Theatre of Martyrdom in the French Reformation', Past \& Present 121 (1988) 49-73.

Nuffel, Herman van, 'De terechtstelling van Egmont en Hoorne en de weerslag ervan op hun tijdgenoten', Brabantse folklore 175 (1967) 267-279.

Outerman, Jacques, Historie der warachtighe getuygen Jesu Christi die de Evangelische waerheyt in veelderley tormenten betuycht ende met haer bloet bevesticht hebben (Hoorn: Zacharias Cornelisz, 1617).

Parker, Geoffrey, Imprudent King. A New Life of Philip II (New Haven 2014).

Parnell, Geoffrey, 'Observations on Tower Green', London Archaeologist 3.12 (1979) 320-326.

Pekelharing, Klaas Rutger, Bijdragen voor de geschiedenis der Hervorming in Zeeland 1524-1572 (Middelburg 1866).

Pollmann, Judith, and Andrew Spicer (eds.), Public Opinion and Changing Identities in the Early Modern Netherlands. Essays in Honour of Alastair Duke (Leiden 2007).

Prak, Maarten, 'Citizens, Soldiers and Civic Militias in Late Medieval and Early Modern Europe', Past \& Present 228 (2015/1) 93-123.

Prims, Floris, 'De briefwisseling tusschen het Antwerpsch magistraat en zijn gedeputeerden juli 1565-april 1566', Bijdragen tot de Geschiedenis 16 (1925) 403-515.

Prosperi, Adriano, Crime and Forgiveness. Christianizing Executions in Medieval Europe (Cambridge, MA 2020).

Roberts, Penny, 'Huguenot Conspiracies, Real and Imagined, in Sixteenth-Century France', in Barry Coward and Julian Swann (eds.), Conspiracies and Conspiracy Theory in Early Modern Europe. From the Waldensians to the French Revolution (Ashgate 2004) 55-70.

Royer, Katherine, The English Execution Narrative, 1200-1700 (Abingdon 2014).

Soen, Violet, 'De reconciliatie van "ketters" in de zestiende-eeuwse Nederlanden (1520-1590')', Trajecta 14 (2005) 337-362.

Soen, Violet, Vredehandel. Adellijke en Habsburgse verzoeningspogingen tijdens de Nederlandse Opstand (1564-1581) (Amsterdam 2012).

Soen, Violet, 'Habsburg Political Culture and Antwerp Defiant. Pacification Strategies of GovernorsGenerals during the Dutch Revolt (1566-1586)', in Ethan Matt Kavaler and Anne-Laure van Bruaene (eds.), Netherlandish Culture of the Sixteenth Century. Urban Perspectives (Turnhout 2017) 167-185.

Soen, Violet, and Johan Verberckmoes. 'Broadsheets Testing Moderation in the Nascent Dutch Revolt', in Andrew Pettegree (ed.), Broadsheets. Single-sheet Publishing in the First Age of Print (Boston 2017) 271-294.

Soen, Violet, 'The Council of Trent and the Preconditions of the Dutch Revolt (1563-1566)', in Wim François and Violet Soen (eds.), The Council of Trent. Reform and Controversy in Europe and beyond (1540-1700) (Göttingen 2018) 255-278.

Spierenburg, Pieter, The Spectacle of Suffering. Executions and the Evolution of Repression, from a Preindustrial Metropolis to the European Experience (Cambridge 1984).

Spruyt, Bart Jan, “En bruit d'estre bonne luteriene”. Mary of Hungary (1505-1558) and Religious Reform', English Historical Review 109 (1994) 275-307.

Tait, Clodagh, 'Adored for Saints. Catholic Martyrdom in Ireland, c.1560-1651', Journal of Early Modern History $5(2001 / 2)$ 128-159.

Terpstra, Nicholas, Religious Refugees in the Early Modern World. An Alternative History of the Reformation (Cambridge 2015).

Thomas, Werner, 'De mythe van de Spaanse inquisitie in de Nederlanden van de zestiende eeuw', BMGN/ Low Countries Historical Review 105 (1990/3) 325-353. 
Tracy, James, 'Heresy Law and Centralization under Mary of Hungary. Conflict between the Council of Holland and the Central Government over the Enforcement of Charles V's Placards', Archiv für Reformationsgeschichte 73 (1982) 284-308.

Tracy, James, Holland Under Habsburg Rule, 1506-1556. The Formation of a Body Politic (Berkeley 1990).

Van Caenegem, Raoul C., Geschiedenis van het strafrecht in Vlaanderen van de XIe tot de XIVe eeuw (Brussels 1954).

Van Dijck, Maarten, 'Tussen droom en daad. De beperkte invloed van de centrale overheid op de rechtspraktijk in Antwerpen en Mechelen gedurende de 15de en 16de eeuw', in Dirk Heirbaut, Xavier Rousseaux and Alain Wijfels (eds.), Histoire du droit et de la justice. Une nouvelle génération de recherches (Louvainla-Neuve 2010) 299-317.

Van Haecht, Godevaert, De kroniek van Godevaert van Haecht over de troebelen van 1565 tot 1574 te Antwerpen en elders. Rob van Roosbroeck (ed.) (Antwerp 1929-1930).

Van Haemstede, Adriaan C., De Gheschiedenisse ende den doodt der vromer Martelaren, die om het ghetuyghenisse des Evangeliums haer bloedt ghestort hebben, van den tijden Christi af, totten Jare M. D. Lix. toe, by een vergadert op het kortste (s.l. 1559).

Van Haemstede, Adriaan C., Historien oft gheschiedenissen der vromer martelaren, die om het ghetuyghenisse des Evangeliis haer bloed vergoten hebben. Van den tijde Christi af, tot den iare M.D.Lxvi. toe, op het cortste by een vergadert (Sedan: Goossen Goebels, 1566).

Van Hernighem, Augustyn, Eerste bouck van beschryfvinghe van alle gheschiedenesse (1562-1572). Alphonse Verheyden (ed.) (Brussels 1978).

Van Loon, Gerard, Antwerpsch chronykje, in het welk zeer veele en elders te vergeefsch gezogte geschiedenissen sedert den jare 1500 tot het jaar 1574 zoo in die toen vermaarde koopstad als de andere steden van Nederland. Frans van Mieris (ed.) (Leiden: Pieter vander Eyk 1743).

Van Schelven, A.A. 'Verklikkers-rapporten over Antwerpen in het laatste kwartaal van 1566', Bijdragen en Mededeelingen van het Historisch Genootschap 50 (1929) 238-320.

Van Vaernewyck, Marcus, Van die beroerlicke tijden in die Nederlanden en voornamelijk in Ghendt. $1566-$ 1568. Ferdinand Vanderhaeghen (ed.), 4 vols. (Ghent 1872-1881).

Vermeersch, Louise, Multimedia in de stad. Interacties tussen het geschreven, gedrukte en gesproken woord in de Gentse publieke sfeer (1550-1585). PhD diss., University of Ghent, 2018.

Verwerft, Bart, De beul in het Markizaat van Antwerpen tijdens de Bourgondische en Habsburgse periode (1405-1550). MA thesis, University of Ghent, 2007.

Vrolijk, Marjan, Recht door gratie. Gratie bij doodslagen en andere delicten in Vlaanderen, Holland en Zeeland (1531-1567) (Hilversum 2004).

Waite, Gary, 'Staying ALIVE. The Methods of Survival as Practiced by an Anabaptist Fugitive, David Joris', The Mennonite Quarterly Review 6 (1986) 46-57.

Westerhof, Danielle, Death and the Noble Body in Medieval England (Woodbridge 2008).

Weert, Josse de, 'Chronycke van Nederland, besonderlyck der stadt Antwerpen, sedert denjaere 1097 tôt den jaere 1565', in Charles Piot (ed.), Chroniques de Brabant et de Flandre (Brussels 1879) 72-172.

Wells, Guy E., Antwerp and the government of Philip II, 1555-1567. PhD diss., Cornell University, 1982.

Wouk, Edward H. 'Antoine Perrenot de Granvelle, the Quatre Vents Press, and the Patronage of Prints in Early Modern Europe', Simiolus 38 (2015) 31-61.

Yasuhira, Genji, 'Delimitation of the "Public" and Freedom of Conscience. Catholics' Survival Tactics in Legal Discourses in Utrecht, 1630-1659', Early Modern Low Countries 3 (2019/1) 81-114.

Zagorin, Perez, Ways of Lying. Dissimulation, Persecution, and Conformity in Early Modern Europe (Cambridge, MA 2014).

Zijlstra, Sanne, Om de ware gemeente en de oude gronden. Geschiedenis van de dopersen in de Nederlanden, 1531-1675 (Hilversum 2000). 